\title{
Comparative analysis of four maple species for syrup production in south-central Appalachia
}

\author{
Jacob D. J. Peters, ${ }^{a}$ Ryan D. Huish, ${ }^{\mathrm{b}} *$ Dakota C. Taylor, ${ }^{\mathrm{a}}$ and Benjamin A. Munson ${ }^{\mathrm{a}}$ \\ The University of Virginia's College at Wise
}

Submitted January 17, 2019 / Revised March 16, June 26, and September 21, 2019 / Accepted September 21, 2019 /

Published online March 6, 2020

Citation: Peters, J. D. J., Huish, R. D., Taylor, D. C., \& Munson, B. A. (2020). Comparative analysis of four

maple species for syrup production in south-central Appalachia. Journal of Agriculture, Food Systems, and

Community Development, 9(2), 267-276. https://doi.org/10.5304/jafscd.2020.092.015

Copyright (C) 2020 by the Authors. Published by the Lyson Center for Civic Agriculture and Food Systems. Open access under CC-BY license.

\begin{abstract}
Sugar maple (Acer saccharum L.) is a key cultural and economic resource from eastern Canada to southcentral Appalachia. Environmental uncertainties could create problems for this iconic species, in particular affecting the southern extent of its range and thus increasing the need for alternative species in maple syrup production. To mediate uncertainties, some producers tap additional species, including box elder (Acer negundo L.), red maple (Acer rubrum L.), and silver maple (Acer saccharinum L.). For viable marketability, sap from alternative species should be comparable to sugar maple in volume and sugar concentration. In the 2016 and 2017 tapping seasons, data were collected on sap volume and sap sugar concentration (SSC) for each

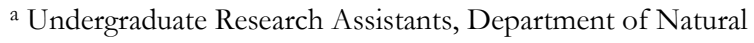
Sciences, The University of Virginia's College at Wise. Jacob Peters is currently a master's candidate in biology at James Madison University.

b * Corresponding author: Ryan D. Huish, Associate Professor of Biology, Department of Natural Sciences, The University of Virginia's College at Wise; 1 College Avenue; Wise, Virginia 24293 USA; rdh5b@uvawise.edu
\end{abstract}

of these maple species. Sap parameter performance data revealed box elder and to a lesser extent silver maple as the most appropriate alternative species for syrup production in the south-central Appalachian region, while red maple, which is a commonly tapped species in northern regions, performed comparably in SSC but very poorly in sap volume in this study. Diversifying sap sources could provide additional sap and tree counts available to producers, allowing for more varied management strategies to mediate climatic variations and uncertainties. This diversification can also allow for industry expansion into areas without sufficient sugar maples and potentially create a new product niche in the maple industry, which can promote rural economic development in southcentral Appalachia through ways compatible with other sustainable agroforestry and outdoor tourism efforts.

\section{Keywords}

Maple Syrup, Sugar Maple, Silver Maple, Red Maple, Box Elder, South-central Appalachia, Agroforestry, Non-Timber Forest Products 


\section{Introduction}

Sugar maple (Acer saccharum L.) is a significant economic and cultural resource from eastern Canada to south-central Appalachia. For centuries, North Americans have been extracting sap from maple trees to concentrate into syrup and other foodstuffs; these maple products have become a notable part of North American economies. With a US $\$ 147$ million industry in the U.S. (U.S. Department of Agriculture [USDA] National Agricultural Statistics Service, 2017) that nevertheless supplies less than $20 \%$ of domestic syrup consumption, there is significant potential for U.S. industry growth (Farrell \& Chabot, 2012). However, the potential in the southern range for maple tapping is generally overlooked in the maple industry and related research.

South-central Appalachia has seen an economic decline, largely due to the fading coal industry (Lobao, Zhou, Partridge, \& Betz, 2016; Maggard, 1994; Taylor, Hufford, \& Bilbrey, 2017). In pursuit of economic recovery, some communities are switching to a more tourism-based economy, which could benefit from the sustainable use of natural resources such as non-timber forest products like maple syrup. Maple tapping, when done according to industry standards (Heiligmann, Koelling, \& Perkins, 2006), does not significantly harm the trees, but rather relies on healthy, longlived trees and forests, and therefore incorporates and encourages sustainable stewardship and provides lucrative alternatives to timbering. A more robust maple industry in this region could help promote rural economic development through product sales and associated opportunities for agritourism, particularly in January through March, when other tourism opportunities may be reduced. Annual maple festivals, which are common in areas with a prevalent maple industry, can generate significant revenue (Farrell \& Chabot, 2012) and provide opportunities to advertise other area attractions. Through sound management and planning, maple-tapping operations generally are environmentally sustainable (Clark \& McLeman, 2011). However, agritourism should be conducted with due environmental consideration so as not to put significant pressures on forest ecosystems.

Maple syrup production is heavily linked to climatic conditions, as the flow of maple sap depends on frequent freeze-thaw cycles and other variables (Skinner, DeGaetono, \& Chabot, 2010). Maple tapping in south-central Appalachia—at the farthest and warmest extent of the sugar maple's range-is therefore particularly sensitive to variations in climatic conditions that can affect maple syrup production negatively in this region during some years. Other environmental stresses, such as climate change, create additional concerns for maple syrup producers in all regions, a major concern being maple tree resilience to changes (Kuehn, Chase, \& Sharkey, 2017; Rapp et al., 2019). This cultural icon may be threatened with population range shifts, decreased health, lower sap volume, and inferior quality, all increasing the need to identify alternative species for syrup production (Houle et al., 2015; Kawasaki \& Uchida, 2016; Skinner et al., 2010).

Alternative sap sources could particularly benefit the southern portion of the range of sugar maple, in south-central Appalachia, which includes northeastern Tennessee, southwestern Virginia, northwestern North Carolina, southeastern Kentucky, and West Virginia. Maple tapping has long been a part of the culture of south-central Appalachia, but it is mainly restricted to high elevation areas where sugar maples grow. If alternative maple species can be found to be suitable, then syrup production could expand within the region, helping preserve its cultural heritage and promote food system resilience. Furthermore, a thriving maple tapping industry could encourage good ecological management practices for forest lands and wetlands to maintain valuable species and habitats.

In searching for alternative species for syrup production, one of the most important factors to consider is the capacity to produce a high volume of sap that contains enough sugar to be economically viable for syrup production. When producing maple syrup, sap is boiled typically until the sugar concentration is $66^{\circ} \mathrm{Bx}^{1}$ (roughly $66 \%$ sugar by mass). Considering that the ratio of sap to syrup

\footnotetext{
${ }^{1}$ Degrees Brix $\left({ }^{\circ} \mathrm{Bx}\right)$ indicates the sugar content of an aqueous solution. One degree Brix is one gram of sugar per 100 grams of solution.
} 
generally ranges from 40:1 to 60:1, the initial sap sugar concentration (SSC) is an important consideration (Blouin, 1992; Kort \& Michiels, 1997; Munson, 1989). A viable alternative for maple syrup production, therefore, should reasonably contain, on average, an SSC of at least $1 \%$ and have a competitive volume of sap production when compared to sugar maple.

There are several groups of trees from which syrup can be produced, including birches (Betula spp.), walnuts (Juglans spp.), and maples (Acer spp.) (Farrell, 2013). The species most commonly utilized for maple syrup production are sugar maple and, to a lesser extent, red maple (Acer rubrum), which are abundant in New England and Canada (Farrell \& Chabot, 2012). Some producers also tap alternative maple species, including box elder (Acer negundo) and silver maple (Acer saccharinum). Previous studies in Canada on box elder (Blouin, 1992; Kort \& Michiels, 1997) and in Illinois on silver maple (Crum et al., 2004) suggest that these species potentially have commercial value in the syrup industry. Furthermore, the alternative species of box elder, red maple, and silver maple have a broader geographic and habitat range than sugar maple (USDA Natural Resources Conservation Service [NRCS], 2019), which could facilitate expansion in the region to areas with insufficient populations of sugar maple.

Research on maple sap is generally conducted in northern regions, with little data on sap parameter performance of maples in the southern Appalachian region. This study, done during the 2016 and 2017 tapping seasons, investigates the comparative sap production volume and SSC of mature and wild box elder, red maple, silver maple, and sugar maple trees across several counties and four states in the south-central Appalachian region, in order to better comprehend the potential for diversifying the maple tapping species in this region.

\section{Methods}

Eight sites were selected to represent gradients across southwest Virginia, and also to include representative sites farther across the geographic range to include possible diversity of individual trees within the region (Figure 1). In total, data were collected from three sites in 2016, and an additional five sites in 2017 (eight total). Data were collected from 25 box elders, 57 red maples, 24 silver maples, and 46 sugar maples across the eight sites (Table 1). Sites were named for the closest neighboring city or town.

Tree selection and tapping were conducted according to guidelines from the North American Maple Syrup Producers Manual (Heiligmann et al., 2006). Only trees with a diameter at breast height $(\mathrm{DBH})$ greater than $30 \mathrm{~cm}$ were considered for tapping. Trees with a DBH greater than $50 \mathrm{~cm}$ were eligible to receive two taps with the stipulation that the taps be located $180^{\circ}$ around the trunk from each other. To avoid bias in tap orientation and placement, a random bearing and height (80-160 $\mathrm{cm}$ ) was chosen, with care taken to avoid previous seasons' tap holes and visible wounds on the tree. Tap holes were drilled at a slight upward angle (10 degrees) and no more than two inches into the wood, using a $5 / 16$ " bit. The hole was cleared of any debris, and a spile was immediately tapped into place, with galvanized steel buckets with lids placed on every spile to collect sap. Tapping was completed in late January and early February and proceeded for the following four to six weeks.

Early-spring xylem sap flow for syrup production is dependent on several climatic variables, including barometric pressure, precipitation, and temperature cycles (freezing night temperatures and thawing day temperatures) (Skinner et al., 2010). Sap volume data were collected for each individual tap when these environmental variables aligned to initiate sap flow. The sap was emptied into weighing buckets and placed on a hanging scale, and sap production levels for each tap were recorded in kilograms. Sugar concentration of the fresh sap was measured in ${ }^{\circ} \mathrm{Bx}$ with a refractometer and recorded each time that sap was actively flowing at the time of sap collection. One drop of fresh sap was collected from the spile onto the refractometer. The refractometer was cleaned with deionized water and a disposable, lint-free tissue between measurements and was periodically zeroed, using deionized water, to ensure accuracy.

Sap production data were aggregated per tap by species to obtain the total amount of sap produced by a single tap throughout a season of data collection. Data were analyzed in an $\mathrm{R}$ program- 
ming environment, using data.table, dplyr, and ggplot2 packages (Dowle \& Srinivasan, 2016; Wickham, 2016; Wickham, François, Henry \& Müller, 2018). Due to the nonparametric nature of both SSC and sap production data (Shapiro-Wilk test, $p<0.001$ ) and equal variance of SSC (Levene test, $p=0.3334$ ) and sap production (Levene test, $p=0.3334)$ across species, median values were used for pairwise Wilcoxon rank-sum tests to compare values between species.

\section{Figure 1. Map of Field Sites}

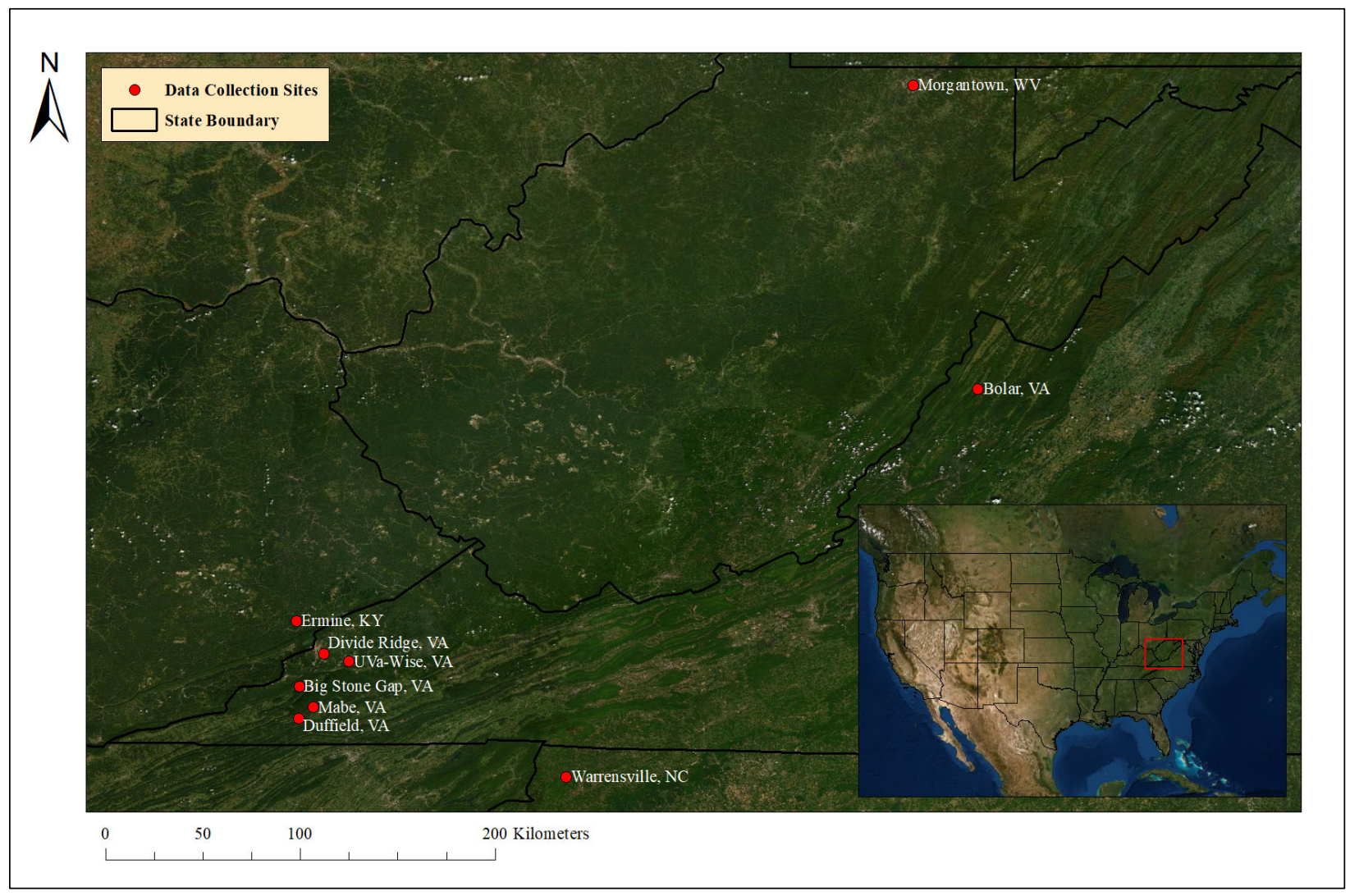

Map service layer credits: Source: Esri, DigitalGlobe, GeoEye, Earthstar Geographics, CNES/Airbus DS, USDA, USGS, AeroGRID, IGN, and the GIS User Community.

Table 1. Field Site Summary

\begin{tabular}{|c|c|c|c|c|c|}
\hline \multirow[b]{2}{*}{ Site } & \multirow[b]{2}{*}{ Elevation $(\mathrm{m})$} & \multicolumn{4}{|c|}{ Total No. of Taps } \\
\hline & & Box Elder & Red Maple & Silver Maple & Sugar Maple \\
\hline Warrensville, North Carolina & 1035 & - & 2 & - & 5 \\
\hline Duffield, Virginia & 413 & - & 1 & 3 & - \\
\hline Big Stone Gap, Virginia a & 442 & 15 & - & 21 & 2 \\
\hline Wise, Virginia & 758 & 5 & 6 & - & - \\
\hline Dixiana, Virginia a & 789 & - & 26 & - & 15 \\
\hline Ermine, Kentucky & 387 & - & 5 & - & 5 \\
\hline Bolar, Virginia a & 763 & - & 14 & - & 12 \\
\hline Morgantown, West Virginia & 280 & 5 & 3 & - & 7 \\
\hline Total & - & 25 & 57 & 24 & 46 \\
\hline
\end{tabular}

a Sites where data were collected in both 2016 and 2017. 
Table 2. Sap Parameters Per Tap by Species

\begin{tabular}{lrrrc}
\hline & Box Elder & Red Maple & Silver Maple & Sugar Maple \\
\hline Mean Sap Production & $13.69 \mathrm{~kg}$ & $5.71 \mathrm{~kg}$ & $9.37 \mathrm{~kg}$ & $10.14 \mathrm{~kg}$ \\
Median Sap Production & $11.22 \mathrm{~kg}$ & $\mathrm{~b} 1.88 \mathrm{~kg}$ & $\mathrm{~b} 5.18 \mathrm{~kg}$ & $\mathrm{a} 6.15 \mathrm{~kg}$ \\
Maximum Sap Production & $48.06 \mathrm{~kg}$ & $25.69 \mathrm{~kg}$ & $53.46 \mathrm{~kg}$ & $34.16 \mathrm{~kg}$ \\
Minimum Sap Production & $0.06 \mathrm{~kg}$ & $0.00 \mathrm{~kg}$ & $0.00 \mathrm{~kg}$ & $0.06 \mathrm{~kg}$ \\
Mean SSC & $1.3^{\circ} \mathrm{Bx}$ & $1.4^{\circ} \mathrm{Bx}$ & $1.6^{\circ} \mathrm{Bx}$ & $1.5^{\circ} \mathrm{Bx}$ \\
Median SSC & $\mathrm{c} 1.2^{\circ} \mathrm{Bx}$ & $\mathrm{b} 1.3^{\circ} \mathrm{Bx}$ & $\mathrm{a} 1.5^{\circ} \mathrm{Bx}$ & $\mathrm{a} 1.5^{\circ} \mathrm{Bx}$ \\
Maximum SSC & $2.0^{\circ} \mathrm{Bx}$ & $3.0^{\circ} \mathrm{Bx}$ & $2.8^{\circ} \mathrm{Bx}$ & $2.7^{\circ} \mathrm{Bx}$ \\
Minimum SSC & $0.5^{\circ} \mathrm{Bx}$ & $0.7^{\circ} \mathrm{Bx}$ & $1.1^{\circ} \mathrm{Bx}$ & $0.7^{\circ} \mathrm{Bx}$ \\
\hline
\end{tabular}

Note: SSC=sap sugar concentration. Superscript letters for median sap production and SSC denote significantly similar values (e. g., all values denoted with "a" are statistically different from "b" and "c," but not significantly different from other values denoted with "a").

Table 3. Pairwise Comparisons Using Wilcoxon Rank Sum Test: Sap Production

\begin{tabular}{llcc}
\hline & Box Elder & Red Maple & Silver Maple \\
\hline Red Maple & $0.00089 *$ & - & - \\
Silver Maple & $0.0479{ }^{*}$ & 0.64670 & - \\
Sugar Maple & 0.76196 & $0.00004 *$ & $0.00824^{*}$ \\
\hline
\end{tabular}

* Statistically significant

The approximation of potential syrup production was calculated with the median sap volume per tap and median SSC values for each species, and utilizing the improved formula for the Jones "Rule of 86" as adjusted by Perkins and Isselhardt (2013): $S=(87.1 / x)-0.32$, where $S$ is the initial sap volume required to produce one unit of syrup and $x$ is sap sugar concentration in ${ }^{\circ} \mathrm{Bx}$. Syrup volume produced can then generally be calculated as syrup volume $=$ sap volume $\times(1 / S)$. The number of taps needed to produce one unit of syrup was calculated by $S /$ median sap volume produced per tap. Syrup produced from 100 taps was calculated by $(100 \times$ median volume produced per tap $) \times(1 / S)$. The sap volume was measured in kilograms and converted to liters (using an approximated 1:1 ratio) and to gallons (using the volume conversion for water of 1 gallon=3.79 kg). Syrup production volume is reported in both liters, and also in gallons for the convenience of maple tappers.

\section{Results}

Mean and median sap production per tap by species and range values are shown in Table 2. Box el- der had the highest sap yield, followed by sugar maple, silver maple, and red maple. Sugar maple and box elder showed no significant difference in the median volume of sap produced per tap per season $(p=0.76)$, but box elder and sugar maple both had a higher median sap volume per tap than red maple $(\phi<0.0009$, $p<0.0001)$ and silver maple $(p<0.048$, $p<0.0083$ ) (Table 3). Figure 2 illustrates the range and variation in sap production per tap by species. Box elder had the largest range in sap volume produced per tap, followed by silver maple and sugar maple. Red maple had the narrowest range in sap volume per tap. Sugar maple and red maple had more consistent sap volumes, with $50 \%$ of the data falling in narrower ranges than for box elder and silver maple.

The mean and median SSC by species and range values are shown in Table 2 . The analysis of median SSC data shows that sugar maple and silver maple sap had the highest median SSC, with no significant difference $(p=0.168)$. The red maple median SSC was significantly lower than both sugar and silver maple $(p<0.0035, p<0.00063)$, while box elder had a significantly lower median SSC than sugar maple, silver maple, and red maple $(p<0.005)$ (Table 4). Range and variation in SSC per tap by species are further illustrated in Figure 3. Red maple demonstrated the widest range in SSC, while silver maple had the narrowest range and showed the most consistent SSC, with $50 \%$ of data points falling within the narrowest range.

An approximation of potential capacity for syrup production based on the median values of sap production and SSC for each species is pre- 
sented in Table 5. This table helps illustrate the comparability of species more clearly and indicates that while box elder sap contained significantly less SSC than the three other species, it could produce the most syrup from the same number of taps due to its high volume. Median sap volume for box elder was two and six times higher than for silver maple and red maple sap volume, respectively, while SSC was only 0.1$0.3^{\circ} \mathrm{Bx}$ less. In contrast, while silver maple and red maple sap had a significantly higher SSC than box elder sap, their approximate performance for conversion to syrup requires almost two to five times more taps.

\section{Discussion}

The results of this region-specific study suggest that box elder is the best alternative species for potential syrup production volume in south-central Appalachia. The syrup produced from box elder trees, however, requires $25 \%$ more sap than sugar maple and silver maple to produce one unit of syrup, while red maple syrup requires $15.5 \%$ more sap. Fuel efficiency in boiling down the sap is an important factor; however, if syrup volume produced per tap is the ultimate consideration, then box elder performs even better than sugar maple in the region. Because SSC can vary widely (Table 2), if producers test the SSC of individual trees and focus sap collection on those with higher SSC, then conversion of sap to syrup ratios could be improved.

Availability and accessibility are significant factors in selecting maple trees for tapping, and different species may be more readily available in different areas. Therefore, while box elder performs best in this region, silver maple, which showed excellent comparability in SSC and reasonable volume pro- duction, may also be a suitable alternative maple sap source for producers to consider. Our data suggest that red maple is not a suitable alternative syrup species for this region, although it is commonly tapped in northern regions.

Taste tests should be conducted to further clarify the suitability of each species before significant investments are made into syrup production using alternative species. Producers could conduct preliminary taste tests on small batches of alternative syrups and mixed-species syrups in order to gain insights into their suitability.

While sap volumes reported here could be expected to increase if trees are tapped using 


\section{Figure 3. Sap Sugar Concentration by Species}

The horizontal line bisecting each box represents median values, with $50 \%$ of data points falling within the box, and the upper and lower $25 \%$ of data points falling along the vertical lines above or below the box. Filled circles placed above or below the plot represent outliers that are more than two standard deviations from the mean.

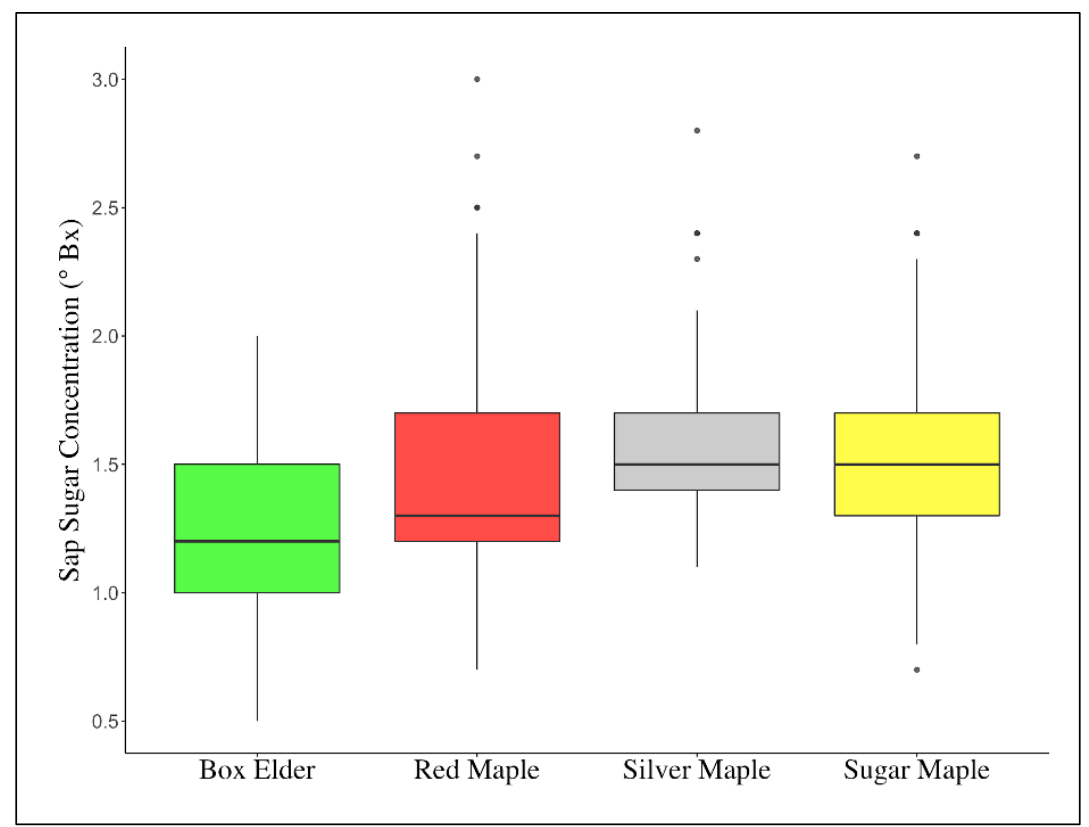

gies. For example, maple tree flowering in early spring marks the end of the tapping season, due to changes in the sap that occur when flowering of the tree has begun. Incorporating multiple species into syrup production can allow producers to stagger their tapping schedules based on flowering cycles, as red maple and silver maple bloom earlier than sugar maple and box elder. This might help extend the tapping season and mediate weather inconsistencies early and late in the season.

In addition to differences in flowering schedule, and the associated potential length of the tapping season, each of these alternative species has other unique characteristics for potential producers in south-central Appalachia to consider. All the species

modern methods such as vacuums and tubing, SSC values reported here are lower in this region than values commonly found in northern regions for sugar maple. More sap is therefore required by producers in the southern region to produce similar volumes of syrup. The comparability of box elder and silver maple with sugar maple for syrup production in this region-specific comparison is therefore particularly informative.

The inherent challenges of the maple tapping industry in south-central Appalachia underscore the potential benefit of alternative maple species for tappers there. If producers can access varied species and therefore a larger number of trees to tap, they can employ strategic management strate- studied can be successfully planted out of their natural elevation ranges; however, box elder and silver maple are naturally riparian species, growing at lower and wetter elevations, while red maple is found across low and high elevations and sugar maple is generally found only at higher elevations. Box elder and silver maple may be good options for producers in areas with lower elevation and wetter habitats that are less desirable for other agricultural and forestry activities, and where those species may already be occurring.

The habitat versatility and broad distribution of box elder and silver maple suggest that these species may be less sensitive to climate and weather fluctuations, which could provide a more resilient

Table 5. Potential Capacity for Syrup Production by Species

\begin{tabular}{lcccc}
\hline & Box Elder & Red Maple & Silver Maple & Sugar Maple \\
\hline Initial sap volume to produce 1 unit of syrup & 72.26 & 66.68 & 57.75 & 57.75 \\
Taps needed to produce 1 liter (gallon) of syrup & $7(25)$ & $36(135)$ & $12(41)$ & $10(27)$ \\
Syrup produced from 100 taps in liters (gallons) & $15.61(4.12)$ & $2.80(0.74)$ & $9.36(2.47)$ & $14.48(3.82)$ \\
\hline
\end{tabular}

Note: Values are calculated using median sap volume and median SSC and the improved formula for the "Jones Rule of 86 " created by Perkins and Isselhardt (2013). 
sap source for producers. Throughout this study, it was also noted consistently that box elder flowed on days when other species did not and also seemed to flow for longer periods after a freezethaw cycle. Further research into the flow-day cycles per species would be informative, if indeed one species performs better during warm spells and other climate fluctuations.

The wide range of SSC between individual trees in this and other studies shows potential for selective breeding to improve sap quality over time (Crum et al., 2004). Box elder and silver maple can be propagated through softwood cuttings (Ingram $\&$ Schutzman, 2013), and producers are encouraged to test the SSC of trees currently available for tapping to identify preferred individuals to propagate through softwood cuttings into new areas. Box elder and silver maple also have faster growth rates than sugar maple, so trees could reach a tappable size in 15-20 years, rather than the 40-60 years necessary for sugar maple (Crum et al., 2004; USDA Natural Resources Conservation Service, 2019). However, box elder and silver maple are not as long-lived as sugar maple, so producers would need to be more active in regeneration to maintain their tree stands for long-term production.

\section{Conclusion}

These results support the suitability of box elder and silver maple as sap sources. These alternative species can provide more tappable trees, and consequently more sap volume, thus allowing for more varied management, which could help to sustain the southern maple syrup industry through climatic variations and uncertainties. Diversifying tappable maple species may also provide an opportunity to expand the industry within this region to areas without sufficient sugar maples.

This could also lead to a unique southern niche in the maple syrup industry. Marketing is one of the most significant strategies for improving the economic impact of maple syrup (Farrell \& Chabot, 2012). The market viability of southern maple syrup could be enhanced when advertised as a unique syrup, produced from just one alternative sap species or a specified blend, and sold in smallvolume containers to emphasize its quality and rarity (Blouin, 1992; Kort \& Michiels, 1997). Further research into taste tests and consumer preferences is important if producers plan to incorporate large percentages of alternative sap into their syrup production. Similarly, research into the phytochemistry of alternative maple saps-such as antioxidant levels or other beneficial compounds and desirable flavors - could identify other distinct, marketable advantages (or disadvantages) of tapping particular alternative maple species.

The use of box elder and silver maple as sap sources presents the potential to give maple tapping a larger foothold in south-central Appalachia and a broader economic impact, such as through supporting larger product yields and also encouraging outdoor tourism such as maple festivals. Furthermore, increasing the maple species tapped across the diverse woodlands of south-central Appalachia encourages food system resilience and sustainable land use, preserving the cultural heritage, natural beauty, and environmental health of this unique ecological region.

\section{Acknowledgments}

We would like to sincerely thank the SAMaRA (Southern Appalachian Maple Research and Activities) team members who helped in the data collection for this analysis, including students from the University of Virginia's College at Wise (Alex Allen, Skyler Allen, Brooke Colley, Katlin Dellis, Leon Dreher, Layton Gardner, Kyle Hill, Michael Hinkle, Kaitlyn Kessinger, David Kihiu, Tre Mullins, McKenna Robinson, Conner Stanley, and Eric White); a faculty member and student from West Virginia University (Jamie Schuler and John Howell); and community members Mike Puffenbarger, Melissa Ailstock, Ed Ailstock, and Abigail Ailstock (Southernmost Maple), Seth and Sheryl Long (Southdown Farms), Ammon, Magnolia, and Abraham Huish (Appalachian Cove Forest Farm and Homestead), and Wheeler Munroe (Waterfall Farm). 


\section{References}

Blouin, G. (1992). Manitoba maple — an untapped resource. A preliminary report on the feasibility of developing a viable industry in the Canadian prairie provinces based upon the utilization of products derived from the sap of Manitoba maple (Acer negundo L.). (Misc. report catalog no. 19647). Prince Albert, SK: Canada-Saskatchewan Partnership Agreement in Forestry, Forestry Canada, Northwest Region. Retrieved from http://www.cfs.nrcan.gc.ca/publications/?id=19647

Clark, K., \& McLeman, R. A. (2011). Maple sugar bush management and forest biodiversity conservation in eastern Ontario, Canada. Small-scale Forestry, 11(2), 263-284. https://doi.org/10.1007/s11842-011-9183-X

Crum, M. L., Zaczek, J. J., Carver, A. D., Williard, K., Buchheit, J. K., Preece, J. E., \& Mangun, J. C. (2004). Riparian silver maple and upland sugar maple trees sap sugar parameters in southern Illinois. In D. A. Yaussy, D. M. Hix, R. P. Long, \& P. C. Goebel (Eds.), Proceedings of the 14th Central Hardwood Forest Conference, Wooster OH (pp. 122-129). Newtown Square, PA: U.S. Department of Agriculture, Forest Service Northeastern Research Station. Retrieved from https://www.fs.fed.us/ne/newtown square/publications/technical reports/pdfs/2004/316papers/CrumGTR316.pdf

Dowle, M., \& Srinivasan, A. (2016). data.table: Extension of 'data.frame.' R package version 1.10.0. Mountain View, CA: H2O.ai. Retrieved from https://CRAN.R-project.org/package=data.table

Farrell, M. L., \& Chabot, B. F. (2012). Assessing the growth potential and economic impact of the U.S. maple syrup industry. Journal of Agriculture, Food Systems, and Community Development, 2(2), 11-27. https://doi.org/10.5304/jafscd.2012.022.009

Farrell, M. (2013). The sugarmaker's companion: An integrated approach to producing syrup from maple, birch, and walnut trees. White River Junction, VT: Chelsea Green.

Heiligmann, R. B., Koelling, M. R., \& Perkins, T. D. (2006). North American maple syrup producers manual (2nd ed.). Columbus: Ohio State University Extension.

Houle, D., Paquette, A., Benoî, C., Logan, T., Power, H., Charron, I., \& Duchesne, L. (2015). Impacts of climate change on the timing of the production season of maple syrup in eastern Canada. PloS One, 10(12), e0144844. https://doi.org/10.1371/journal.pone.0144844

Ingram, D. L., \& Schutzman, B. (2013). Landscape plant propagation information. Gainesville: Institute of Food and Agricultural Sciences, University of Florida. Retrieved from https://hort.ifas.ufl.edu/database/lppi/index_scientific.shtml\#A

Kawasaki, K., \& Uchida, S. (2016). Quality matters more than quantity: Asymmetric temperature effects on crop yield and quality grade. American Journal of Agricultural Economics, 98(4), 1195-1209. https://doi.org/10.1093/ajae/aaw036

Kort, J., \& Michiels, P. (1997). Maple syrup from Manitoba maple (Acer negundo L.) on the Canadian prairies. The Forestry Chronicle, 73(3), 327-330. https://doi.org/10.5558/tfc73327-3

Kuehn, D., Chase, L., \& Sharkey, T. (2017). Adapting to climate change: Perceptions of maple producers in New York and Vermont. Journal of Agriculture, Food Systems, and Community Development, 7(3), 43-65. https://doi.org/10.5304/jafscd.2017.073.020

Lobao, L., Zhou, M., Partridge, M., \& Betz, M. (2016). Poverty, place, and coal employment across Appalachia and the United States in a new economic era. Rural Sociology, 81(3), 343-386. https://doi.org/10.1111/ruso.12098

Maggard, S. W. (1994). From farm to coal camp to back office and McDonald's: Living in the midst of Appalachia's latest transformation. Journal of the Appalachian Studies Association, 6, 14-38. https://www.jstor.org/stable/41445659

Munson, P. (1989). Still more on the antiquity of maple sugar and syrup in aboriginal eastern North America. Journal of Ethnobiology, 9(2), 159-170. Retrieved from https://ethnobiology.org/sites/default/files/pdfs/JoE/92/Munson.pdf

Perkins, T. D., \& Isselhardt, M. L. (2013). The "Jones Rule of 86" revisited. Maple Syrup Digest, 25A(3), 26-28. Retrieved from https://mapleresearch.org/wp-content/uploads/1013jonesruleof86.pdf

Rapp, J. M., Lutz, D. A., Huish, R. D., Dufour, B., Ahmed, S., Morelli, T. L., \& Stinson, K. A. (2019). Finding the sweet spot: Shifting climate optima for maple syrup production in North America. Forest Ecology and Management, 448, 187197. https://doi.org/10.1016/i.foreco.2019.05.045

Skinner, C. B., DeGaetono, A. T., \& Chabot, B. F. (2010). Implications of twenty-first century climate change on Northeastern United States maple syrup production: Impacts and adaptations. Climatic Change, 100(3-4), 685-702. https://doi.org/10.1007/s10584-009-9685-0 
Taylor, B., Hufford, M., \& Bilbrey, K. (2017). A green new deal for Appalachia: Economic transition, coal reclamation costs, bottom-up policymaking (Part 1). Journal of Appalachian Studies, 23(1), 8-28. https://doi.org/10.5406/jappastud.23.1.0008

U.S. Department of Agriculture, National Agricultural Statistics Service (USDA NASS). (2017). United States maple syrup production. Harrisburg, PA: USDA NASS, Northeastern Regional Field Office. Retrieved from https://www.agmrc.org/media/cms/2017_Maple_Syrup_BB42E310D83BA.pdf

USDA Natural Resources Conservation Service (USDA NRCS). (2019). The PLANTS Database. Greensboro, NC: USDA, Natural Resources Conservation Service, NPDT National Plant Data Team. Retrieved January 12, 2019, from http://plants.usda.gov

Wickham, H. (2016). ggplot2: Elegant graphics for data analysis. New York: Springer-Verlag. https://doi.org/10.1007/978-3-319-24277-4 9

Wickham, H., François, R., Henry, L., \& Müller, K. (2018). dplyr: A grammar of data manipulation. R package version 0.7.8. San Francisco, CA: RStudio. Retrieved from https://CRAN.R-project.org/package $=$ dplyr 